\title{
Witchcraft and selfcraft
}

\author{
The problem
}

W H E N I was a graduate student, my doctoral supervisor, Max Gluckman, telephoned me to put off an appointment, saying that his dentures had broken. Always the anthropologist, he responded to the expression of my sympathy by asking, rhetorically, why the misfortune had befallen him just when it did, and then, following this question with another, why he would choose to answer by invoking chance rather than witchcraft. Though I am late on the uptake, I would like here to explore these questions asked me by my teacher so many years ago.

Like most if not all of his colleagues, Gluckman had been profoundly influenced by Evans-Pritchard's stupendous study of witchcraft and oracles among the Azande (singular, Zande) of Center Africa (1937). Though that study is well-trodden ground for anthropologists and philosophers alike (e.g. see Wilson), it still provides a rich ethnographic and analytic resource in relation to the problems Gluckman posed ( $\mathrm{r}$ ).

(1) Though, in what is to follow, it suits my purpose to rely on Evans-Pritchard's ethnography, of course his picture of the Azande is not unproblematic, as Geertz's critique of Evans-Pritchard highlights (1983). However, notwithstanding the important contribution of the school of anthropological thought focussed on ethnography as writing, there is something much too easy about Geertz's argument. To maintain that Evans-Pritchard's famous clarity of style betrays a mighty sociocentric conceit appears to court the admonishment that, in addition to being an intrinsically interpretive exercise, ethnographic translation should also be unclear. Surely the relevant objective is to 'clarify'-i.e. make intelligible for the readerthe apparently radical other, even if clarification entails the alter-ation of its own conditions. It is not obvious that clarification of this kind necessarily demands, by contrast to directness, elegance and limpidity of style, a 'shaded', 'unflattened' and 'tendentious' manner of expression (qualities that, as Geertz says [1983: 74], well characterize his own brilliant and rhetorically imposing style). At any rate, though Evans-Pritchard could not have simply escaped the colonial mentality of his time and culture, and though of course there is something telling about the relationship between Evans-Pritchard's ethnographic authority and his ethnographic style, it is by no means transparent to me, as will come out in the course of this essay, that he did simply presume there is nothing about the Azande that is new under the British sun. Indeed, the penetrating interpretive sensibility of Witchcraft, Oracles and Magic... (not to mention the corpus of his work)-as measured by the degree to which the book begins to question Western categories of thought (such as 'non- 
Indeed, it's a good bet that when Gluckman's teeth broke that morning, the contingency of the event brought Evans-Pritchard's monograph to his mind, leading him to reflect aloud on the questions at point.

Evans-Pritchard employed the first of Gluckman's questions-'Why me, why now?'- to suggest that an account of contingent misfortune in terms of witchcraft or the like is really far from silly. After all, so far science has had little to offer in the way of an answer to the question of contingency. As to Gluckman's second question, that of why some people account for such contingent misfortune by reference to an enchanted rather than natural universe, Evans-Pritchard could answer only by pointing to the 'mystical' premises of Zande thought. His answer is unsatisfactory, not because it is mistaken, but because he was inclined to think of mystical notions, in contrast to scientific ones, as mistaken. Mystical notions, he wrote, are 'patterns of thought that attribute to phenomena supra-sensible qualities... which they do not possess' (1937: 12-emphasis added).

In the present exercise, I want to project a different, more positive picture of what Evans-Pritchard called mystical notions. I aim to do so

contradiction')-stands as compelling testimony that he did not. Which is one reason why I find Geertz's critique too easy, and perhaps even (despite his outright declaration of admiration for Evans-Pritchard [1983: 70]) a bit mean.

Of course, numerous others have pointed to flaws in Evans-Pritchard's analysis. In her introduction to the abridged edition of Evans-Pritchard's book, Gillies suggests that, still under the spell of functionalism, EvansPritchard gave Zande socicty a misleading homeostatic cast (1976). Gluckman himself was fond of observing that Evans-Pritchard failed to analyze satisfactorily Azande thought and practice in relation to their social organization. He, and others, did supply analyses of this kind for other peoples (see Gluckman r965: ch. 6). In her compact appreciation of Evans-Pritchard's work, Mary Douglas does a neat job of teasing out of the monograph on the Azande how their witchcraft ideas depend on their political institutions (1980: ch. 5).

Any definition of the situation will be the more imposing for having behind it institutional relations of power. But, as especially Foucault and Bourdieu have thought through, knowledge, considered as practice rather than sheer thinking stuff, has its own ways of making power. In his brilliant study of terror and healing in Colombia, Taussig has argued that it is precisely this sort of power Evans-
Pritchard, in the account of Zande witchcraft, failed to discern (1987: 463-4). Like Geertz, Taussig is a bit too quick and easy with Evans-Pritchard's explanatory analysis, overlooking the phenomenological and praxiological implications of Evans-Pritchard's wonderfully precocious and powerful theses about 'ideas imprisoned in action' and about the inverse relation between the notions of contradiction and situation. But my argument about the Azande finds a striking parallel in Taussig's observation that 'coincidence and sorcery pose questions concerning one's life's environment, opening out the world as much as closing it in', and that it is therefore 'woefully mistaken' to call this a 'closed system' (r987: 465). Indeed, Taussig's broad thesis about the terrible healing power of shamanic, 'epistemic murk' is of a piece with my understanding here, that we need to learn from as well as about the other. However, whereas for him basic ambiguity or uncertainty is primarily a question of epistemology and power (cf. Surin 1993), for me it is at bottom a matter of ontology and ethics. In her deeply felt and moving book on the violence of hunger and suffering in Brazil, Nancy Scheper-Hughes has thought to ask about, in respect of Evans-Pritchard's study, the connection between witcheraft and ethics (1992: 21). 
by pointing to the ontological and epistemological conditions for offering and maintaining such notions. In so doing, $I$ hope to throw light in the direction of Gluckman's questions. More particularly, I want to address the question of moral accounting in relation to contingent suffering. I take it that, by juxtaposing the explanatory concepts of chance and witchcraft, what Gluckman basically wanted to know is why he was culturally disposed to understand his misfortune in terms of natural causation rather than moral agency (cf. Gluckman 1965: 218). Whereas 'chance' (as Gluckman used it that morning) connotes an indifferent probability, 'witchcraft' conjures up agential doings on the part of someone or other.

My argument throughout turns on a notion of practice, as will become clear (2). To make the argument, I will compare and contrast the Zande oracular procedures to certain pseudo-psychotherapeutic ones from a modern setting. The instance of pseudo-psychotherapy is taken from Peter McHugh's rigorous ethnomethodological study of the organization of meaning in social interaction, based on a 'laboratory experiment' in which college student volunteers were told, deceptively, that they were undergoing a new, simplified form of psychotherapy (1968). Given the patently contrived circumstances of the ethnomethodological example, the use of it as a prop for my argument is bound to give some readers misgivings. It is important, then, to make clear from the outset just why it is suitable here.

I was drawn to the example many years ago, by its stunning likeness to the proceedings of the Zande poison oracle. The issue here is not whether the example is odd and artificial (it is, by definition), but rather, given this condition, what argumentative purpose it is meant to serve. In line with the basic intentions of McHugh's ethnomethodological exercise, the exceptional nature of the example-designed as it is to obstruct the actor's taken-for-granted social world-serves to disclose expectancies of ordinary interaction that are fundamental but so routine and familiar they normally go unnoticed. The expectancy I want to bring into relief, in relation to Zande witchcraft and the poison oracle, is the critical manner in which much Western social interaction is produced and maintained by the individual's sense of himself as morally self-contained.

It needs to be borne in mind, then, that what is crucial to my argument is not the ethnographic verisimilitude of the example but the

(2) I say ' $a$ ' rather than 'the', since the notion of practice I have in mind differs significantly from Bourdieu's. As I understand it, Bourdieu's 'practice' is largely powerdriven, whereas the notion deployed here is keyed to ethics. Even so, I have learned a great deal from Bourdieu's rich expositions. I have developed this point about 'practice' elsewhere (Evens 1993). 
thesis of a certain practice pertaining to selfhood in the West. This thesis does not stand or fall with the example. Indeed, the practice I have in mind, which I call here 'selfcraft', when taken broadly scarcely stands in need of documentation-its existence as a diagnostic feature of Western thought and action is testified to by the philosophical corpus of discourse in the West, from Augustine's penitentially self-searching Confessions to Foucault's impassioned and sustained interrogation, in one work after another, of the self thus fashioned. The example from McHugh is not adduced to demonstrate the thesis of selfcraft, but, rather, a job for which it is eminently suited by virtue of its outlandishly extreme constitution, to furnish a perspicuous picture, an iconic model, of how selfcraft works.

That said, however, it would be a mere disciplinary conceit to conclude that simply because it was generated artificially, the example is of no ethnographic value. On the contrary, what it lacks in ethnographic richness and intensity, it makes up for in, as one might expect from McHugh's purpose of uncovering presuppositions of everyday interaction, ethnographic depth. Hence, though I do not wish to suggest that the example may be taken to represent all psychotherapeutic interaction, I would contend that the particular picture of selfcraft the example projects is diagnostic of a great deal of modernity, including, it so happens, much psychotherapy, if thinkers like Lacan (1978), Foucault (1965), Deleuze and Guattari (1977) have anything to say about the matter.

Although I am primarily interested here in the question of moral accounting, it is convenient to start my discussion in terms of the so-called problem of rationality, the problem to which EvansPritchard's great monograph most directly addresses itself. In these times, when the only worthy intellectual position is deemed one that has already succeeded itself (a post-erior position), 'the rationality debate' may seem old-fashioned. This is odd when one considers that the successor-volume to the debate's standard edited collection (Bryan Wilson's Rationality [1970]), first appeared only about a decade ago (Hollis and Lukes' Rationality and Relativism [1982]). But if Tambiah's recent Louis Henry Morgan Lectures are any indication (1990), and a 'straight from the horse's mouth' monograph like Akiga's Story is not to be ignored (3), then the problem stands.

(3) By contrast to an 'if I were a horse' monograph (to use Evans-Pritchard's pithy characterization of a certain kind of ethnocentric anthropology [1965]). Akiga's account of the Tiv, his own people, though not unmediated by Christian training and Western education, exhibits an otherness that scems in the end to resist reduction to figurative language (1939). For a monograph that, in my view, transcends the 'if I were a horse' fallacy, 
I mention this consideration because it is my impression that there exists today a forceful, if still limited, disciplinary tendency to conduct one's ethnographic and anthropological researches as if there is no problem of rationality. I suggest that especially for reasons of the prevailing influence exercised by the approach from figurative language, making a tropological anthropology, and by the intellectual deconstruction of Western reason, it is sometimes thought or even taken for granted that the problem of rationality was simply a figment of the anthropologist's (romantic or colonial) imagination(4). The critical

yet cannot be regarded as 'straight from the horse's mouth', see Leenhardt's Do Kamo (1979). The 'writing ethnography' thinkers (see Crapanzano 1979 as well as Clifford 1982) have done anthropology a decided service by salvaging Leenhardt's work from the relative obscurity to which it had been consigned by the linguistic (structuralist and antiphenomenological) deconstruction of the idea of primitive mentality. Leenhardt's account of a genuine otherness that is irreducible to metaphorical language is distinguished by its remarkably open ontological sensibility.

In his richly argued critique of the notion of mentalities, the classicist G. E. R. Lloyd has questioned the wholesale use of the metaphorical-literal dichotomy to describe socio-cultural orders in which the dichotomy is epistemically unavailable (1990). Though he argues that the emergence of this dichotomy cannot help but change perception, he does not seem to hold with the possibility of a reality in which the categories of metaphor and letter are not simply unavailable but in a sense ontologically mistaken. On the contrary, for all his acute attention to the historical character of Western categories, and to the condition of different contexts and styles of thought, he seems still to presume standard Western ontology-as when he declares, e.g., 'Collectivities do not think, only individuals do'! (I990: 5). In at least four other places, I have argued forthrightly against the universal anthropological application of the opposition between the metaphorical and the literal, but on ontological rather than simply epistemological grounds (Evens 1983; 1989; 1993; 1995).

Sperber too rejects the ('symbolist') approach that reduces to figurative language the apparently irrational statements often reported in ethnographies (1985). Taking a well considered rationalist perspective keyed to cognitive psychology, he argues that all peoples necessarily entertain some representations as representations rather than as facts per se and which correspond to ideas understood only incompletely. On his approach, then, if I understand him correctly, when the ethnographer is earnestly told by his informants to go, say, dragon hunting, s/he should take 'dragon' neither as a statement of fact nor a figure of speech, but as a perfectly ordinary representation that happens to be vague and one or more times removed from the cognitive plane of brute factuality. However, since even when it is entertained as indistinct and only factually-involved (rather than factual per se) the idea of a dragon continues to challenge the received suppositions of Western reality, the problem seems to be left intact. The difference between Sperber's position and mine is radical, and may be summed up by comparing his notion of 'semi-proposition' with my notion of 'half-logic' (Evens 1983). Both posit fuzzy boundaries. But whereas 'semi-proposition' is epistemological, distinguishing cognitions that are vague and unspecific, 'half-logic' is paraontological, conflating (as instructed by 'the peoples of ethnography') the cognitive with the bodily, the ideal with the real.

(4) Somewhat ironically, in view of his rationalism-and although it is certain he is no post-structuralist-Lévi-Strauss' powerful deconstruction of totemism heralded the tropological dissolution of the problem of rationality. For that matter, so did Evans-Pritchard's Nuer Religion, in which the analysis from figurative and poetic language displays a subtlety and depth perhaps unparalleled by anything since, including Geertz's hermeneutics (notwithstanding the direction of his critique of Evans-Pritchard [see above, n.l]).

For a skillful example of a recent work in which it appears simply to be taken for granted that there is no problem of rationality, see Maurice Bloch's Lewis Henry Morgan lectures 
intellectual pounding taken by the idea of rationality, and by the consequential authority that this idea has fostered, has been profoundly remedial. But the crucial consideration that a line demarcating reason from magic, or science from metaphysics, cannot be fixed in absolute terms, hardly means that no line may be drawn at all. Were we to think that, the spirit of absolutism (or, to use the cant postmodernist term, totalism) intrinsic to the received idea of rationality will have triumphed, not been defeated. Lines of demarcation come in many kinds, including the kind I aim to draw here: the basic but fuzzy kind, the kind that both separates and connects. As I see it, the failure of much recent anthropology to acknowledge fundamental, authentic otherness signals, for obvious reasons, what Wittgenstein would have called a loss of problem.

Though an abundance of excellent ethnographic work has appeared since the publication of Evans-Pritchard's study of the Azande, barring mindless presentism, it still makes good sense to employ that study in an attempt to think again through a fundamental problem. Admittedly, such an exercise carries risks, especially that of closure by canonization. But when it comes to rethinking ontological and epistemological aspects of the problem in mind, the restudy of this classic work offers the student the strategic advantage of a case-material that, for reasons of its

(1992). Bloch's symbolic interpretations of rituals, myth, etc. strike me as always rich and often brilliant. But the problem of rationality presented by the ethnographical observations Bloch analyzes, the problem of what sense it makes in the first place to entertain what appear to us as patently nonsensical representations, goes largely unaddressed by him-as if to say that once we have down the 'cultural logic' of representations that equate birds with spirits, or men and women with cattle, we have exhausted the anthropological problem presented therein. Bloch's book, no more than many other recent works, seems to take for granted that the problem of rationality has been done away with by symbolic anthropology and the culturological thesis of troping the light fantastic.

Obeyesekere's recent book (1992), on the other hand, espying a residual Frazerian aspect to structuralism, still finds it necessary to demonstrate that there is no problem of rationality. Mounting a virtual diatribe against Sahlins' thesis regarding the deicidal/regicidal killing of Captain Cook in the South Seas (and in the process giving a fresh, multi-faceted professional substance to this sort of ritual killing), Obeyesekere argues that the very idea that the Hawaiians could have mistaken a human being for a god is a product of a Western, colonialist mythological conceit. His critique is keyed to a Weberian (and, I venture, Malinowskian) notion of 'practical reason' as a kind of universal biological and cognitive capacity. His ethnohistorical scholarship seems exemplarily meticulous, and therefore may present an interpretive challenge that needs to be met. But his argument from the concept of pragmatic reason, despite his explicit avoidance of utilitarian reductionism, seems to make it impossible for any people, anywhere or anytime, to entertain notions in which 'the real' and 'the ideal' somehow include each other. Ironically, then, it would seem that, while seeking to destroy European colonialist mythmaking, he manages also to promote, uncritically, one of the key principles from which that mythmaking has drawn epistemological sustenance-rationality in the sense of logos. In this regard, though he stresses practical rather than intellectual reason, he remains close to Lévi-Strauss. His concept of practical reason, no less than Lévi-Strauss' of intellectual structure, deploys-if in a more particularistic and context-sensitive way-a thesis of figurative usage in order to save 'native peoples' from the charge of prelogical mentality. 
intimate association with the disciplinary emergence of the problem, lends itself uniquely to the possibility of an interpretive Gestalt switch.

The switch of interpretation I intend here has two moments: I) that a practice like Zande witchcraft is, in a limited but profound sense, open rather than closed; and 2) that therefore, in studying a people like the Azande, we can learn not only about them but also from them. What we learn is, I think, that moral accounting is predicated most fundamentally on a perception of discretion as a primordial feature of the world, and not in the first place as a reasoned product of Kantian individuals (5).

Though in its crucial turn to a notion of practice, my argument is in keeping with a good deal of current anthropology, in its openly ontological intentions and unembarrassed projection of 'otherness' as such, the argument departs sharply from the regnant disciplinary emphases of tropology and broadside relativism. In order to deal with the apparent difference between peoples anthropology has traditionally studied and the people of anthropology, the present essay takes another direction. Under the liberal anthropological watchword 'different tropes for different folks', relativism and tropology move decidedly to avoid the presumptive attribution of inferiority to the other. For all that, however, in as much as the very idea of figurative language is, like that of rationality proper, peculiarly Western, by reducing cultural difference to a question of such language, relativism and tropology manage to collapse the other into the occidental self. In so doing, ironically and despite appearances, they drive even deeper that self's arrogation of epistemic rank (6).

By contrast, the present essay, under the philosophical influence of Émmanuel Levinas (1969, 1991), embraces the difference between self and other as no less irreducible than relative, such that it can be meaningfully engaged but not finally resolved. Moreover, far from presupposing the superiority of the occidental self, my approach

(5) We learned long ago, from Kenneth Read's remarkable essay on the GahukuGama, that the Kantian individual is not a universal (1955). Though Read does not suggest there that Western thought can take a lesson from the Gahuku-Gama about the nature of discretion, it is tempting to read The High Valley, another landmarking work by him, as an attempt on his part to see just what can be learned from this people about what it means to be a human being (1965).

(6) There is no room here to argue this point. I can, however, bare the bones of the argument I have in mind, by quoting (a
Heideggerian) Derrida on the subject of the intrinsic connection of the dualism of 'metaphor' and 'letter' with 'Western philosophy as metaphysics', as well as on the implicitly repressive character of this connection (r978: 27; see also 1982; and Bruzina 1978): 'Metaphor in general, the passage from one existent to another, or from one signified meaning to another, authorized by the initial [dualistic] submission of Being to the existent, the [dualistic] analogical displacement of Being, is the essential weight which anchors discourse in metaphysics, irremediably repressing discourse into its metaphysical state'. 
attributes to the other, on the basis of 'ethics' rather than exotics, a certain axiological primacy. It thus flatly refuses the association of otherness with inferiority, the stupid but impelling association of our time. And, by privileging the other in a fundamental way, it does so without collapsing the difference of the other into a relativistic symmetry, the fearfulness of which rests with its necessary description of all value judgment as essentially arbitrary, a matter of power rather than principle.

Put more simply, it is argued here that there is something profoundly true about the world as the Azande find it, an oracular world inhabited by witches. This truth (bearing on the existential nature of discretion) is worth knowing, but, because it really is other or unfathomable in our own received terms, cannot be assimilated by us save at a certain ontological cost-the cost of the world as we know it, which is to say, not the enrichment, as one may be used to hearing, but the veritable transformation of our-selves.

\section{Witchcraft, poison oracles and rationality}

The ethnography of Azande oracles is well known. The Azande make all of their important determinations and decisions by consulting their oracle, which operates through the administration of a strychine-like substance to fowls. Thus, having suffered a misfortune and so regarding himself as bewitched, a Zande will consult the oracle in order to discover the identity of the culprit. Keeping to questions that can be answered only by Yes or No, he feeds the oracular substance to a chicken, instructing it to kill the chicken if he has identified the witch correctly and to save it if he has not.

From the perspective of empirical science, the question which arises about such a system of inquiry is how it can last-for it seems riddled with contradictions. In response, Evans-Pritchard took two main lines of argument. First, he observed that 'Contradictions between their beliefs are not noticed by Azande because the beliefs are not all present at the same time but function in different situations' (1937: 475). This observation is a corollary of his argument that 'The Zande actualizes [his] beliefs rather than intellectualizes them... [T] heir ideas are imprisoned in action and cannot be cited to explain and justify action' (1937: 82-3). In other words, he argued that, in a sense, among the Azande a contradiction may not be a contradiction, because their beliefs 
are not primarily matters of theory but of practice. Obviously, this argument anticipates Bourdieu by more than three decades. Second, Evans-Pritchard pointed out that, once its initial premises are granted, the oracular practice of the Azande proceeds in tolerably rational fashion, even though it is finally organized to reinforce itself.

Here is an example of how contradictories may be separated situationally, keeping the contradiction out of mind's sight. The Azande do understand that the substance they employ for oracular purposes is what we would call a natural poison. As a result, they also know that if it is administered in sufficiently large doses, it necessarily kills. Yet this knowledge has no bearing on their conviction that when the substance is given to a fowl in the oracular situation, the fowl's fate is owed to oracular, not natural causes. As Evans-Pritchard put it, the two sorts of knowledge 'are functions of different situations and are uncoordinated' (1937: 3 19). Plainly, as it is hard for modern thought to see why the naturalistic knowledge is irrelevant to the oracular situation, EvansPritchard's argument depends here on the very idea of situation. Suffice it to say that, if his argument is to work, 'situation' must be defined overridingly by reference to immediate practical aims and consequences, making theoretical knowledge as such, that is, knowledge that transcends particular situations, definitively irrelevant and phenomenologically indistinct.

What about contradictions that occur within the oracular situation itself, the kind we might expect in the course of, say, a scientific experiment? For example, what do the Azande do when the oracle contradicts itself irrecusably? Here, they respond in a manner that tends to secure their system of thought from the threat of such contradictions but is nonetheless significantly rational in the received sense of the term.

It is the case that, on important issues, after receiving the oracle's answer, the Zande will repeat the question, this time, however, reversing the order of the answers in relation to the chicken's reactions. That is to say, if in the first run Yes was linked to the outcome of death, in the second No will be so linked. In other words, the Azande check the reliability and consistency of the oracle, by, as we would put it, repeating the experiment. Or, the Zande might test the oracle's power of discrimination by seeing if it gives different answers to different questions.

Now, when the Azande are confronted with an oracle that contradicts itself or with one that is undiscriminating (one that gives the same response no matter what the question), evidently they feel compelled to account for the oracle's failure. In this regard, they behave much as would be expected under the rule of logic as such-insofar as the 
oracle's failure goes wholly unaccountable, conviction in the oracular system as a whole is eroded.

To account for the failure, the Azande appeal to initial conditions of the case at hand. For example, they might suggest that a taboo had been violated or that the oracle substance had been extracted from the wrong sort of creeper. It is crucial to see, though, that they do not select in explanation just any initial conditions; they select ones that, given reality as the Azande find it, logically entail the consequence in question. Once it is admitted that there are two kinds of creeper, one of which produces an overpotent oracle substance, it becomes logically appropriate to argue that in the case of a poison that kills fowls indiscriminately, the wrong kind of creeper is to blame.

The Azande restrict their explanatory selection of initial conditions in yet another, perfectly logical, way. They tend to look to ones that admit of independent testing. Plainly, were they to test their conjecture about an excessively strong oracle substance by citing the fact that it kills the fowls indiscriminately, their argument would be stupidly circular. Instead, they are likely to shelve the substance for several months, waiting for it to 'cool' (1937: 33I). Should it still prove defective after this 'test', Azande will be inclined to abandon the explanation of 'excessive potency' as wrong and seek another.

Furthermore, in their accounting procedures, the Azande not only appeal to initial conditions but also implicate what, given their reality, we would regard as universal laws or regularities. The explanations the Azande offer of oracular failure would be perfectly illogical if this people did not take for granted certain lawful relations, such as the operation of the poison oracle through the medium of fowls and the connection between the observance of taboos and the success of the oracle. Obviously, if for the Azande the world were such that fowls thrive on the oracle substance or that the violation of taboos has no impact on the effective operation of that substance, then, their explanations could have no logical force.

I have just described five features of the operation of the Zande oracle which are correct by reference to the strict sense of rationality: 1 ) Azande test their oracle for reliability; 2) they do not ignore contradictions resulting from these tests, but rather seek to account for them; 3 ) in explaining them, they appeal to specific initial conditions that can deductively generate the explicandum; 4) these initial conditions do admit of independent testing; and 5), in arriving at their explanations, Azande appeal not only to initial conditions but also to universal laws or regularities. 
These five ways of approaching a practice constitute ingredients of scientific thinking. Yet, Evans-Pritchard found the Azande explanations of the oracle's failure wanting, calling them, in a felicitous but pejorative phrase, 'secondary elaborations of belief'. As he saw it, the explanations serve, not really to explain the contradictions, but to explain them away, thus exposing the oracle, to the outside observer, as dogma. Indeed, so effective did he find the defense mechanisms of the Zande structure of belief, that he opined (1937: 3 I9): 'Let the reader consider any argument that would utterly demolish all Zande claims for the power of the oracle. If it were translated into Zande modes of thought it would serve to support their entire structure of belief'. How, then, do the Azande manage such epistemological closure?

There are at least two critical ways in which Zande reasoning falls short here of logical rigor. First, for all of the apparent testing of the oracle's reliability, the questions asked of the oracle are, generally speaking, too imprecise to determine whether or not the answers pan out. Thus, instead of asking, Will I kill a bushbuck if I go hunting tomorrow?, the Zande is likely to ask whether or not he will have a good hunting season if he hunts in one part of the bush rather than another. Obviously, whereas the precise content of the former question would allow the answer to be easily tested against the empirical outcome, the content of the latter-with its vague notions of 'a good hunting season' or 'parts of the bush'-makes the nature of the connection between the answer and the empirical outcome far less determinate. Moreover, the vague character of the binary answers also leaves a great deal of space for ad hoc interpretation. Thus, in the case of a man who was informed by the oracle that he would die if he made a certain journey, but who proceeded to make the journey without mishap only to make it again and then die, it was said that the oracle had not been wrong but had looked ahead (1937: 348). Clearly, given the broad content of the questions asked of the oracle and the vague character of the answers, there is always enough interpretive room to save the oracle from refutation. As Evans-Pritchard put it, 'The answers either cannot be tested, or if proven by subsequent events to be erroneous permit an explanation of the error' (1937: 340).

The second critical way in which Zande accounting procedures fail to meet the demands of logical inquiry bears directly on the issue of testability. As a crucial measure of scientific rationality, the explicans should be testable independently of what it is introduced to explain. I have already indicated that in explanation of their oracle's failures, Azande do cite conditions that yield to independent testing. But such 
testability is a matter of degree, and in the final analysis it is especially in connection with this parameter that Zande accounting procedures come up short when they are evaluated by reference to rationality as such.

Take the case of an oracle substance that kills fowls indiscriminately. As stated above, Azande are likely to attribute this unsatisfactory result to an excessively potent oracle substance, one extracted from the wrong sort of creeper, and to store the substance, allowing time for it to 'cool'. Evans-Pritchard records that if, after it has been allowed to 'cool', the substance still fails to perform satisfactorily, Azande 'either throw it away or seek to discover whether witchcraft or some other cause is now responsible for its failure to give correct judgements' (1937: 33I). Now, on the one hand, should they throw it away, we may safely infer that whether their explanation of the substance's faultiness is right or wrong is not for the Azande a question worth pursuing. So much for their spirit of scientific inquiry. On the other hand, should they seek to determine whether witchcraft or something else is the cause of the problem, they fare no better on the canons of explanation proper. Evans-Pritchard does not identify the causes other than witchcraft the Azande might adduce to account for the oracle's poor showing. But it is fair to assume that whatever these causes may be, should they too fail to convince, the Azande would then turn to witchcraft as the cause. That is to say, eventually the Azande will arrive at witchcraft to explain the fault. And, we already know what the test for witchcraft is-the poison oracle! In the end, thus, the Zande accounting procedures describe a circle.

Here, then, we see why Evans-Pritchard found the Zande's system of thought to be notably closed. Construed as a system of rational inquiry, the Zande poison oracle involves too much imprecision of language and too little possibility of testing explanations independently of the effects that need explaining. The imprecision of the explanatory predicates invites ad hoc hypotheses or 'explaining away', and the sharp curtailment of continuing explanatory referral to logically higher-level statements-that is, the tautological closure of the system-makes deep refutation unthinkable (cf. Popper I968: ch.6). In a word, considered as a system of thought, the Zande oracle cannot be falsified.

Exhibiting an umbilical attachment to anthropological views he did so much to refute, views which picture primitive peoples as mentally incompetent, Evans-Pritchard was inclined to attribute the unfalsifiable nature of this system to the fact that the system is epistemologically founded in mysticism. 'Azande see as well as we', he wrote, 'that the failure of their oracle to prophesy truly calls for explanation, but so 
entangled are they in mystical notions that they must make use of them to account for the failure' (1937: 339).

Today, however, we know that unfalsifiability is hardly confined to mystical systems of thought. In the wake of the work of such scholars as Burtt, Hanson, Popper, Kuhn, Lakatos, Feyerabend, and others, it is plain that science itself is given, perhaps fundamentally, to securing itself against refutation. As a technical concept, 'falsifiability' is due to Karl Popper, whose powerful (if also well-criticized) model of scientific rationality I have been employing all along here as a standard against which to measure the strengths and weaknesses of the Zande oracular system construed in terms of rational inquiry (7). Popper forged his model as a descriptive and normative critique of the received theory of modern science as an inductive endeavor. He finds that the inductivist's affinity to highly probable hypotheses is counter-intuitive to good science (1965: 287). Since that affinity advantages hypotheses that stay close to the known facts, it promotes ad hoc or stop-gap thinking and disadvantages hypotheses that can be tested independently of the facts to be explained. Popper speaks here of 'reinforced dogma', by which he means theoretical representations that are so constructed as to be more or less immune to critical attack ( $1965: 327,334)$. When one considers that their respective subject matters were once taken to define a line of demarcation between magic and science, the degree to which EvansPritchard's analysis of Azande oracles and Popper's critique of the received theory of modern science share a common critical understanding is quite remarkable. In point of fact, I take it that Popper's concept of 'reinforced dogma' and Evans-Pritchard's of 'secondary elaboration of belief' are impressively synonymous.

\section{Selfcraft and foul therapy}

However, it better suits my purpose here to leave off the example of modern science and cite instead a different sort of parallel discourse to Zande oracular practice, but one no less peculiarly modern. In a work in

(7) Needless to say, I am not making an argument on behalf of Popper's theory of rationality, for which countless strong critiques exist (e.g. Feyerabend 1975). I employ it here, not because I believe it can satisfactorily demarcate science from metaphysics, but because it is very helpful in bringing out what EvansPritchard found wrong with the oracular thought of the Azande. As I will come to in the text, my own candidate for such a line of demarcation is not rationality, but the phenomenological emergence of a rule of rationality. A line of this kind is indeed consequential, but no more than any rule can it fix a separate mentality. 
which he investigates the :problem of how meaning is constructed in social situations-the so-called problem of the 'definition of the situation'-the sociologist Peter McHugh describes an experiment he conducted on college students (1968). Having been told that they were testing a new form of psychotherapy, the novelty of which rests with its simplicity, the students were instructed as follows: first, to relate to the therapist a personal problem; second, to ask the therapist questions about the problem, ones which can be answered by only Yes or No, and then to comment on what they take to be the meaning of the answers; and, third, to summarize what they believe they have learned from the therapeutic exchange. Unbeknown to the student, the 'therapist', delivering his 'answer' from another room over an intercom, determined his response by reference to a list of random numbers. In other words, his answers had been predecided and would have been the same regardless of the question. The following is an abridged version of one of the resulting pseudo-psychotherapeutic interactions, though one in which the therapist's answers, instead of being determined simply randomly, were structured to test the strength of the student's faith in the given definition of the situation (1968: 93-8).

Student's account of his problem. I've been attending the University of Miami, until I came up here this year. Last year I met a girl down there and fell in love with her. I want to marry her. However, my brother's met her and he thinks she's too bossy and it'd be a mistake if I married her. My father seems to like her, but my mother hasn't met her yet. I know she's right for me, but how can I convince my brother she is? My mother will make her decision when she meets her, but in the meantime my brother might say something that will influence her before then. My father doesn't talk to my mother, so he won't be any help. I really know she's right for me regardless of what anyone says, but I'll need the go-ahead of my family if everything's to go right.

Question. My brother met the girl I love several months ago, but he doesn't think I should marry her. Should I try to show him she's changed, and will be all right to marry now?

Answer. No.

Comment. You mean I shouldn't try to convince him she's changed, once somebody makes up their mind about something like this there's no changing them. Especially my brother. It's no use even trying. People just hold on to what they believe no matter what, so I'm better off going ahead with another plan. But I still want to change my brother's mind. While it isn't easy to do this by just talking about it, maybe if he sees her he'll realize she's changed and isn't so bossy any more. I hope so.

Question. Could I go about this, instead of telling him, by letting him see her and see that she's changed for himself?

Answer. No.

Comment. You mean that she will be the same to him even if he sees for himself. No matter whether I tell him or he sees it for himself he won't want me to marry her, she'll be just as bossy as ever regardless of how she acts in front of him. Too bad I have a brother like that... The question is, will he change ever, or is there nothing I can do? 
Question. Will he ever change his feelings about her?

Answer. No.

Comment. Hmm. Really? This isn't easy to take, even though I can see what you mean. You told me that it doesn't matter whether he is told, or even if he sees her, he'll stick to his guns and always be against it. This means I can't go on worrying about what he thinks or changing his mind, but concentrate on seeing that he doesn't interfere. Of course, maybe he won't ever change, won't ever like her and always think she's bossy, but still he might realize it doesn't matter to me and I'm going to marry her whatever he says or thinks...

Question. Even if he never likes her, will he decide it's no use doing all this objecting and drop it?

Answer. No.

Comment. He won't drop his objections, but will keep on... [M] father seemed to like her, he doesn't have the same opinion my brother does. And my mother hasn't met her yet, maybe she wouldn't mind either...

Question. Even though my brother disagrees, would the rest of the family go along with the marriage?

Answer. No.

Comment. They won't consent to the marriage. Well, there's nothing left but to break off with the family. That'll be hard on everyone, but after all, I love her and that's the most important thing. You don't go through life with your brother, or your mother and father either... Maybe if I get a job paying good money and could support her, they'd come around later.

Question. If I got a good job with a good steady income, will they agree I made the right choice?

Answer. No.

Comment. Christ, you keep saying no all the time... Maybe I can't influence you either. I mean you keep saying everything I don't want to hear. I mean can this be psychotherapy?...

Question. Do you want me to influence you in this conversation?

Answer. No.

Comment. [15-second silence] Well, maybe it's not put right. I can't make him understand, know about my family that makes them different. These answers, though, I don't know, psychologists must be pretty good to do this. There aren't many who could.

Question. You must be pretty good, aren't you as good as most psychologists?

Answer. No.

Comment. No. No. Wow, he doesn't think he's as good as most psychologists. Wow. So what kind of advice is he giving? Bad advice. This can't be psychotherapy, I mean what kind of help is that? Do you think you're any good, and he answers no. In fact, it's been no to everything I've said. Hasn't it?... Maybe it's no regardless.

Question. Do you say no regardless?

Answer. No.

Comment. Well, that's good. I mean, what would that mean, saying no regardless?... What is the purpose of this? Supposedly a simple method of giving advice. But maybe it's supposed to be so simple even an incompetent psychologist can use it... You can learn something about yourself just by talking about it. Maybe that is their reason here, to teach the person about himself...

Question. Do you think I should marry the girl?

Answer. No. 
Comment. That must be it.,They are trying to find a way of advising that teaches you more about yourself... Even if I get bad advice, I will be better off because I will know myself better after I'm finished... Like I know now for sure I'll marry the girl regardless of what my family says... Before I came in here, though, I didn't know that... So there's something to [this kind of therapy]...

Student's summary of the exchange. For a while I was worried that this was a bad situation. I didn't know how to take your advice when you said you weren't a very good psychiatrist, but then I realized it could still teach you something about yourself... I was especially helped when I realized that I should go right ahead with my plans... Very interesting. Even a poor psychiatrist can be helpful if you just talk about yourself.

It would be hard to find from a modern setting a more stunning, and for that matter entertaining, parallel to the Zande oracle (8). Like the Zande interrogating his chicken, the student put his questions to the alleged therapist in the hope of determining an auspicious course of action and/or remedying an unhappy situation. And, from the perspective of rational inquiry, the No's uttered by the 'therapist' were tied to the student's questions in the identical (heterogeneous) fashion that the binary responses of the poison oracle are to the Zande's. Though the student had ample logical opportunity to refute decisively the definition of his situation, in fact he clung to that definition, always managing to turn contradiction into confirmation: he was told outright by the 'therapist' that the therapy was not much good; the 'therapist's' declaration that the answers were not in fact responsive to the questions was enough to give the student pause but not to move him to abandon the definition of the situation; the fact that all the responses were the same regardless of the question would have put off, as we know, even a Zande; the illuminated paradox of the 'therapist's' reply of 'no' to the question of 'Do you say no regardless?' did not even break the student's epistemic stride. In the end, the student was able to reinforce the therapeutic definition of the situation by telling himself-an ad hoc gambit or secondary elaboration of belief if every there was one-that he had learned his own mind and that the foul therapy to which he

(8) Since writing this essay, I have discovered that David Zeitlyn, in an ethnomethodological analysis of Mambila 'spider' divination (1990), has also drawn the parallel to McHugh's experiment, employing the work of McHugh's teacher, the founder of ethnomethodology, Harold Garfinkel. However, unlike the present paper, the phenomenology of which is heterodox and ontologically ambitious, Zeitlyn's essay is a straightfoward exercise in 'conversational analysis'. I might add that Zeitlyn roundly misrepresents an earlier essay of mine (Evens 1983). He cites it as an example of the anthropological admonition to construe the sort of thinking in question here-thinking that customarily exhibits indifference to contradiction-as non-standard logic (1990: 665, n.13). This is very curious since, wholly to the contrary, that essay very plainly constitutes (as is broadcast even in the essay's Abstract) a carefully considered repudiation of 'the other logic' thesis in anthropology, and it stands on all fours with the present exercise's phenomenological and situationalist turn toward nondualism and a concept of practice. 
had been subjected was meant to facilitate just such onanistic enlightenment.

Here, then, is a mode of inquiry, intimately associated with a preeminently modern practice-let us call it 'selfcraft'- that seems no less unfalsifiable than Zande oracular thought. Yet, in principle, the pseudopsychotherapeutic proceedings, though they had a hidden purpose, were no more founded in mystical notions proper than is bona fide psychotherapy. The considered principles at the core of psychotherapeutic interaction are meant to attribute to phenomena nothing that cannot be derived from empirical observation or logically inferred from it.

\section{Practice and rationality}

If, then, the profound resistence to falsification exhibited by such systems of inquiry is not attributable to mystical notions as such, how can we account for it? By expanding, I think, Evans-Pritchard's situationalist reply to the riddle of when a contradiction is not a contradiction.

Obviously, a system secure from inductive refutation is one in which the particular case in itself can never be adequate to discredit the general case-that is, the case of how things stand in general. Such a logically scandalous condition describes an epistemological state in which, regardless of the particular case, the general case remains always thoroughly presumptive. Since, in this state of reflection, it is taken for granted that the particular case must serve as an instance of the general case, the former can never be understood to run truly contrary to the latter-apparent contrariness will be explained away or disregarded. Put another way, where the general case is utterly taken for granted, where it constitutes the prereflective ground of all reflection, the particular case cannot achieve a degree of differentiation from the general case sufficient to make conceivable employing it to test the validity of its ground. In the event, even apparent contradictions can serve only to confirm the general case (9).

Such blind presumption of the general case obtains under, and only under, conditions where the primary purpose is not truth but 'livability'. In a word, it obtains where the situation is directly defined by

(9) Of course, under these circumstances, the 'general case', no more than the 'particular case', can amount to the inductivist's notion. The blurring of the distinction between the particular and the general must impede the differentiation of generality as it does that of particularity. 
practice rather than theory. Where this condition prevails, what counts in the first place is not whether one's representation of things is a good likeness, but whether one's actions work.

But what does it mean to say in the present connection that something works? As Hume showed (making a nonsense of commonsense empiricism in the process, arch-empiricist though he was), a practical effect is never really closed (see Popper 1972: 4). Since a practical effect cannot provide a rational basis for concluding that what has just happened will continue to happen, in order to assess the significance of such an effect, one must ever look foward to effects yet to come. Accordingly, as Bourdieu says, 'practice is inseparable from temporality', such that it identifies itself 'with the imminent future of the world, postulating the continuity of time' (r990: 81,82). Put differently, practice presumes the general case considered as, not the aggregate whole, but the essentially uncertain or ambiguous whole. The presumption of continuity or generality is not due to a psychological mechanism of association, as Hume thought, but presents the very nature of human practice. In light of this understanding, to say that something works is to say simply that it is livable in the general case, that it allows one to get on with the business of human existence. I take it that this is the import of Evans-Pritchard's finding when, during his fieldwork among the Azande, he decided to regulate his affairs in accordance with the oracle's decisions, and was led to remark (1937: 270): 'I found it as satisfactory a way of running my home and affairs as any other I know of'.

Just as the Zande consulting his oracle is preoccupied with practical rather than theoretical problems, so the student consulting his 'therapist' was concerned to take a decision not simply representing but actually effecting who he is and where he stands in the world. Since a decision of this kind is essentially uncertain and creative, the process of its determination cannot yield to the precise terms of formal logic and the conclusive tests of scientific rationality. Though that process does not wholly lack a theoretical coefficient, the 'theory' attaching to it is consistently enveloped in practice.

It is only when practical problems are differentiated as such, liberating theory to represent itself as above and beyond practice, that it becomes possible to construct a rational system as such. With this onto-epistemological revolution, thought is positioned to stipulate beforehand what will count as evidence for refutation, and, more importantly, that something should so count. For once accounting procedures can present themselves as non-participant in what they aim 
to illuminate, they appear free of the contingencies of practice. In the event, they can project the world as timeless and complete, and therefore as open to a rule of precision and certain truth, of limpid representation and independent testability. At bottom, then, what serves to demarcate the Zande oracle from scientific inquiry is nothing so substantial as the imprecision and circularity of the former, qualities which are not foreign to the practice of science, but the fact that the Azande are not given to the conception of such an epistemological rule: that it is possible to decide beforehand, in theory and out of time, a rule of evidence for falsifying unequivocally the general case can scarcely be dreamt of in their universe.

Thus the imposing degree to which the structures of thought at point here are unfalsifiable may be explained by reference to their primarily practical nature. This account returns us to Evans-Pritchard's precocious solution to the anthropologically pregnant riddle of when a contradiction is not a contradiction, to wit: when it remains 'imprisoned in action'. Taken as an epistemological starting point, practice, though it never lacks for an element of theory, does not admit of the clean (dualistic) break between theory and practice that makes contradiction conceivable and practically relevant as a canonical instrument of thought. The reflective release of theory from practice, though it occasions only a limited freedom, enables theory to represent itself as sui generis, thus projecting the world as concordant to rules of evidence fixed and decisive.

\section{Moral accounting}

At this juncture, I can turn to the question of moral accounting. Perhaps it will have been noticed that, although the proceedings of both the Zande oracle and of McHugh's kind of psychotherapy are indeed practically driven, it is not the case that McHugh's poor dupe lacked access to the canons of rationality proper. Given the modern content and setting of McHugh's experiment, the participating student not only could have appealed to the logical law of non-contradiction but, notwithstanding the practical aim of the interaction, in a certain sense should have. Of course, it is easy to picture even the most savy of rocket scientists falling for McHugh's obnoxious but ingenious sociological con-game.

The epistemological power of practice aside, however, what I want to emphasize now is that in the modern setting, practice is informed by 
theory as such, that is, by theory that (mis)represents itself as essentially free of practice. As a consequence, though it continues to display a mighty resistance to falsification, practice is indeed transformed. The transformation that counts here is that practice tends to lose its moral definition. Perhaps the most visible difference between the Zande oracle and McHugh's therapy is that between witchcraft and selfcraft as modes of forging practical decisions. Though, in light of the philosophy of someone like Kant, at first blush it may seem to us only exactly otherwise, the move from witchcraft to selfcraft also exemplifies a decided shift away from moral towards natural accounting. It marks an ontological shift, from a world which runs most essentially according to moral agency, to one the dynamics of which are principally a matter of mechanical determination. In the former, existence is primarily a question of creative, discretionary selection, as conduced by an existential and ultimately irresolvable ambiguity of selfhood and otherness, and only secondarily 'natural'; in the latter, existence is primarily entitative, a function of natural determinations in which ambiguity is systematically eradicated in favor of self-identity, making moral agency distinctly epiphenomenal (10).

As forms of practice, both witchcraft and selfcraft presume the general case or the whole. But whereas witchcraft points to the essential ambiguity or uncertainty of the whole, selfcraft, by affording the whole the firm boundaries of the individual qua individual, tends to fix or totalize it. Ambiguity stands as a critical condition of the operation of moral force, however, which is nothing if not a creative force for signification under conditions of essential uncertainty. That is to say, on the one hand moral force creates and recreates meaning out of ambiguity; on the other, basic ambiguity calls up, over and over again, the creative force of moral agency. In this light, given its ontological presumption of basic uncertainty, witchcraft may be construed as a mystical practice on the experience of moral force at large in an uncertain world. Though the experience of the world as primordially subject to

(10) Pace Horton, for whom the shift is idiomatic and epistemological rather than ontological. His discussions of the sort of problem that concerns me here are rich and studied (e.g. 1970; 1982). My key point about the phenomenological liberation of theory from practice finds much to go on in Horton's account of the consequences of the 'divorce of secondary theory [by which he means 'theoretical discourse' by contrast to 'everyday discourse' or 'primary theory'] from practical life' (1982: 246). Moreover, I have some sympathy for his (bold) argument that, when it comes to the domain of 'human social life' by contrast to that of 'non-living things', the 'traditonalist' enjoys a certain superiority over the 'modernist' (1982: 249). Nevertheless, though they are too complex to treat here, the differences between his ('intellectualist') approach and mine are, I suspect, profound, centering as they do on the difference between cognitivism and phenomenology, and between epistemology and ontology. 
discretion cannot of itself commit one to a world populated by witches, it certainly provides a genuine basis for the phenomenological emergence of such a world.

If, however, uncertainty is obscured or belittled, selection as a creative, and therefore specifically moral, enterprise makes little sense. By picturing the world in terms of the apparent concrete integrity of the individual, the conceptual confinement of selective force inside the bounds of the individual makes the world appear, accordingly, ever more thingified and certain. As a result, selection itself is projected as a positive rather than intrinsically creative dynamic. Thus, whether we have in mind mechanical computation or instrumental choice, selection is rendered really as natural rather than moral.

No wonder the Enlightenment idea of the moral agent has fallen on hard times-insofar as it is predicated on the self-contained or natural rather than existential individual, it is ultimately self-defeating. The essential ambiguity that is occluded by naturalistic individualism, the ambiguity of the individual that exists outside of and as other to itself, intimates genuine otherness, otherness that is irreducible to the unambiguous. If reduction of moral agency to the self-identical individual undermines the authenticity of otherness, then what sense can it finally make to make it categorically imperative that one should always treat other people as ends in themselves? (I I)

The upshot is that when logic qua logic and selfcraft are added to oracular proceedings, the proceedings are transfigured into therapeutic ones and the situation loses its moral definition in favor of naturalism of one kind or another. Much of modern psychotherapy is predicated on the idea that one can lay oneself open in order to assess and identify one's natural self, as if one possessed a self in the same way that one possesses a heart and lungs. And indeed, McHugh's student, impelled by the aberrant circumstances to carry the therapeutic situation to its solipsistic conclusion, understood himself to have arrived at his decision as if it had been predetermined as a component of his true, innermost self. There is no idea of genuine choice or creative movement in such a decision (12).

(II) Cf. Sartre's critique of Kantian idealism, in which Sartre argues that Kant's affirmation of the other really runs contrary to the essential solipsism of the Kantian thesis of pure subjectivity (1956: $225 \mathrm{ff}$.). My notion of otherness here has been directly inspired by the thematically ethical philosophy of Emmanuel Levinas (e.g. 1969; 1991).

(12) Though Anthony Giddens does not allow Philip Rieff's thesis (about the rise of therapy as a function of secularization and of the moral vacuum created by the weakening of traditional religion) to go unqualified, and he is keen to explore the advantages of the modern sense of self, he certainly focuses the aspect of therapy featured here (1991: 180): "Therapeutic endeavours... take place against the background of sequestration of experience and the internally 
One might be tempted to think much the same of the Zande, though for reasons of reduced rather than unqualified autonomy. Given oracular decision making, he doesn't really grasp the decision as his, and, therefore, strictly speaking, as choice. But he does grasp the answers of the oracle as genuinely responsive, as pronouncements of the other considered as, not a therapeutic or rational interlocutor, but a genuine moral agent. For the Zande, the oracle speaks with the authority of an other that is irreducible to the self and identity (13). By contrast, for McHugh's student the dialogue was reduced to a monologue, a self-certain process of selection in which there is no room for the other qua other and therefore for genuine moral agency.

My response to Gluckman's question, then, is that the phenomenological release of theory from practice, and of the individual from its social context, such that the distinctions are defined dualistically, tends to undermine moral accounting of contingent suffering. For while these grand turns to dualism make scientific inquiry possible, in the end they take the very life out of the idea of moral force.

However, as has become thematic in today's intellectual environment, naturalistic explanation is itself a form of practice and moral discourse-even as it effectively conceals from itself its role in this regard, it takes a stand in and constructs a virtual world. Indeed, though I stand by my foregoing argument, there is even a crucial sense in which modernity and selfcraft may be seen to advance rather than undercut moral agency. But that sense is exceedingly difficult and demands serious discussion in its own right (14). I mention it here for the record,

referential systems of modernity. It is not surprising that many-not all-therapies are oriented primarily towards control. They interpret the reflexive project of the self in terms of self-determination alone, thus confirming, and even accentuating, the separation of the lifespan from extrinsic moral considerations'. In other words, therapy tends to arise with and create social environments in which people, by virtue of a highly exclusive self-identity, are very well insulated from the discretionary power of, and uncertainty presented by, the other.

(13) Cf. Ashis Nandy's witty but scathing critique of the commoditization of the game of cricket in modern India, and therewith of the course of modernization and nationalization in India (1989). In it, Nandy speaks of the 'increasingly less self-critical moral culture of the modern sector in non-modern societies' and observes that both cricket and astrology -each somehow centered in a sense of uncertainty-have the capacity to reaffirm 'the existence of a moral universe' (1989: 102-3): 'Astrology in this part of the world shows all the signs of being not only a reading of the vicissitudes of fate but also an insight into the morality of one's own thoughts and actions, in fact into one's own moral self. At this plane, astrology becomes, however self-contradictory this may sound, a mirror as well as a critique. You see in it not so much your future as your past and your present'.

(14) The possibility of such advance may be seen in relation to the obvious consideration that the fundamentally discretionary nature of witchcraft does not save particular others from being targeted for alienation (as witches, of course). Indeed, as has been well documented, between the $1^{\text {th }}$ and $17^{\text {th }}$ century, whole categories of people in Europe (including lepers, Jews, and 'witches') were subjected to savage torture and capital punishment because 
and also in order to facilitate a concluding observation about the anthropological authority whose remarks began this paper. Deep down, in spite of his anthropologizing about the difference between his and the Zande's views of contingent misfortune, Gluckman knew that moral accounting still counts. For when I pressed him that morning long-past he confessed (a confession he was wont to make whenever something untoward happened to him) that he had been bewitched after all. Only he had no need of a magic oracle to identify the evildoer-the name was a matter of the anthropological record (15).

\section{$R E F E R E N C E S$}

Akiga I939, Akiga's Story (Rupert EAST, trans. \& annot.) (London: Oxford Univ. Press, for the International Institute of African Languages \& Cultures).

BLoch, M., 1992, Prey into Hunter: the Politics of Religious Experience (Cambridge: Cambridge Univ. Press).

Bourdieu, P., 1990, The Logic of Practice (trans) (Stanford: Univ. Press).

Bruzina, R., 1978, Heidegger on the Metaphor and Philosophy, in Heidegger and Modern Philosophy (Michael MurRay, ed.) (New Haven: Yale University Press).

Clifford, James, 1982, Person and Myth: Maurice Leenhardt in the Melanesian World (Berkeley: University of California Press).

Crapanzano, V., 1979, Preface. Do Kamo (trans.), Maurice Leenhardt (Chicago: University Chicago Press).

Deleuze, G. and F. Guattari, r977, Anti-Oedipus: Capitalism and Schizophrenia (trans.) (New York: Viking Press).

Derrida, J., 1978, Force and Signification,

they were held to be morally responsible for contingent misfortunes (see e.g. Ginzburg I991). On the one hand, by sealing off and certifying the self onto- and epistemologically, selfcraft tends to totalize the process of the alienation of the other. By the same token, it vitiates the principle of moral discretion. A self-identical self leaves no room at all for authentic otherness, and therefore, in as much as otherness is a necessary condition of the practice of moral selection, none for genuine moral selection either. On the other hand, by promulgating self-reflexion, selfcraft makes in Writing and Difference (trans.) (Chicago: The University of Chicago Press).

-, 1982, White Mythology: Metaphor in the Text of Philosophy, in Margins of Philosophy (trans.) (Chicago: The University of Chicago Press).

Douglas, M., 1980, Edward EvansPritchard (Penguin Books).

Evans-Pritchard, E.E., 1937, Witchcraft, Oracles and Magic among the Azande (Oxford: The Clarendon Press).

-, 1965, Theories of Primitive Religion (Oxford: The Clarendon Press).

Evens, T.M.S., I983, Mind, Logic and the Efficacy of the Nuer Incest Prohibition, Man (N.S.) $18,111-33$.

-, 1989, The Nuer Incest Prohibition and the Nature of Kinship: Alterlogical Reckoning, Cultural Anthropology 4 (4), 323-346.

-, 1993, Rationality, Hierarchy and Practice: Contradiction as Choice, Social Anthropology I (1B), 10 I-1 18.

-, 1995, Two Kinds of Rationality:

conceivable the opening up of such ultimately suicidal behavior to critical viewing. I have developed this thesis elsewhere (Evens n.d.). For a philosophically magisterial argument in this direction, see Taylor (1989; also 1991); for a strong, thoughtful and well-informed Habermasian account, see McGowan (1991); for a critically reserved but positive sociological slant, see Giddens (199r).

(15) Gluckman and another late, great social anthropologist, Sir Edmund Leach, regarded each other with, so to speak, a sorcerous professional respect (cf. Kuper 1983: ch. 6). 
Kibbutz Democracy and Generational Conflict (Minneapolis: University of Minnesota Press).

-, n.d., Anti-Dualism or Anthropology as Ethics. Unpb. ms.

Feyerabend, P.K., 1975, Popper's Objective Knowledge, Inquiry $17,475 \mathrm{ff}$.

Foucault, M., 1965, Madness and Civilization (trans.) (New York: Pantheon).

GeerTz, C., 1983, Slide Show: EvansPritchard's African Transparencies, Raritan 3 (2), 62-80.

GIDDENS, A., I991, Modernity and SelfIdentity (Stanford: Stanford University Press).

Gillies, E., 1976, Introduction. Witcheraft, Oracles and Magic among the Azande (abridged), E. Evans-Pritchard (Oxford: The Clarendon Press).

GinzBurg, Carlo, 1991, Ecstasies: Deciphering the Witches' Sabbath (trans.) (New York: Penguin Books).

Gluckman, M., 1965, Politics, Lavo and Ritual in Tribal Society (Oxford: Basil Blackwell).

Hollis, M. \& S. Lukes (eds), 1982, Rationality and Relativism (Cambridge, Mass.: The MIT Press).

Horton, R., 1970, African Traditional 'Thought and Western Science, in Rationality, B. Wirson (ed.) (Oxford: Basil Blackwell).

-, 1982, Tradition and Modernity Revisited, in Rationality and Relativism, M. HoLLis and S. Lukes (eds) (Cambridge, Mass.: The MIT Press).

KuPER, A., 1983, Anthropology and Anthropologists: The Modern British School (revised) (London: Routledge).

LACAN, J., 1978, The Four Fundamental Concepts of Psychoanalysis (trans.) (New York: Norton).

LeENHARDT, M., 1979, Do Kamo (trans.) (Chicago: Univ. Press).

Levinas, E., 1969, Totality and Infinity (trans.) (Pittsburgh: Duquesne University Press).

-, 1991, Otherwise than Being or Beyond Essence (trans.) (Dordrecht: Kluwer Academic Publishers).

LLOYD, G.E.R., 1990, Demystifying Mentalities (Cambridge: Cambridge University Press).

McGowan, J., 199r, Postmodernism and its Critics (Ithaca: Cornell Univ. Press).
McHugr, P., 1968, Defining the Situation (Indianapolis \& New York: The BobbsMerrill Company, Inc).

Nandy A., 1989, The Tao of Cricket: On Games of Destiny and the Destiny of Games

(New Delhi: Penguin Books).

ObeYeseKERE, O., 1992, The Apotheosis of Captain Cook: European Mythmaking in the Pacific (Princeton, New Jersey: Princeton University Press).

Popper, K., 1965, Conjectures and Refutations (2nd edn) (London: Routledge \& Kegan Paul Ltd).

-, 1968, The Logic of Scientific Discovery (rev. edn) (London: Hutchinson $\&$ Co. Ltd).

-, 1972, Objective Knowledge (Oxford: The Clarendon Press).

READ, K.E., 1955, Morality and the Concept of the Person among the Gahuku-Gama, Oceania 25 (4): 233-82.

-, 1965, The High Valley (New York: Columbia University Press).

SARTRE, J-P., 1956, Being and Nothingness (trans.) (New York: Philosophical Library).

SCHEPER-Hugres, N., 1992, Death without Weeping (Berkeley: Univ. of California Press).

SpERBER, D., 1985, On Anthropological Knowledge (Paris and Cambridge: Maison des Sciences de l'Homme and Cambridge University Press).

SuRIN, K., 1993, Transform the World, Change Life: Michael Taussig's Poetics of Destruction and Revelation, The South Atlantic Quarterly 92 (2).

Tambial, S.J., 1990, Magic, Science, Religion, and the Scope of Rationality (Cambridge: Cambridge Univ. Press).

Taussic, M., 1987, Shamanism, Colonialism, and the Wild Man (Chicago: Univ. Press).

TAYLOR, C., 1989, Sources of the Self: The Making of Modern Identity (Cambridge, Mass: Harvard Univ. Press).

-, 1991, The Ethics of Authenticity (Cambridge: Harvard University Press).

WiLson, B. (ed.), 1970, Rationality (Oxford: Basil Blackwell).

ZeITLYN, D., 1990, Professor Garfinkel Visits the Soothsayers: Ethnomethodology and Mambila Divination, Man (N.S.) 25, 654-66. 